\title{
Notes on marine meiofauna from muddy bottoms off Málaga (Spain)
}

\author{
L.v. Salvini-Plawen (*), G. Steiner (*) and C. Todt (*)
}

\section{Introduction}

During the ECOMALAGA campaing performed by the Instituto Español de Oceanografía (Málaga/Fuengirola) under the direction of Juan A. Camiñas, it was possible to collect some sediment samples off the region of Málaga (10-13 July, 1997). This was a preliminary test to gain insight in the unknown composition of sediment meiofauna to the western-most Mediterranean Sea, in particular with respect of the influence of Atlantic water and the faunistic status of the Sea of Alborán. Some interesting findings beyond that scope have also been observed and are reported in these faunistic notes.

\section{Results}

This report concerns three dredged samples (M 1 - M 3) carried out with the author's "meiobenthic sledge" and one grab sample (M 4). All samples were collected from muddy sediments off-shore between Málaga and Vélez-Málaga:

M 1 = off Málaga, $36^{\circ} 35.53^{\prime} \mathrm{N}, 4^{\circ} 19.22^{\prime} \mathrm{W}, 197 \mathrm{~m}$ to $36^{\circ} 35.29^{\prime} \mathrm{N}, 4^{\circ} 18.75^{\prime} \mathrm{W}, 211 \mathrm{~m}$;

M 2 = off Málaga, $36^{\circ} 38.51^{\prime} \mathrm{N}, 4^{\circ} 20.46^{\prime} \mathrm{W}, 80 \mathrm{~m}$, to $26^{\circ} 38.66^{\prime} \mathrm{N}, 4^{\circ} 20.10^{\prime} \mathrm{W}, 79 \mathrm{~m}$;

M 3 = off Vélez-Málaga, 36 $36.37^{\circ} \mathrm{N}, 4^{\circ} 02.73^{\prime} \mathrm{W}$ $403 \mathrm{~m}$, to $36^{\circ} 36.31^{\prime} \mathrm{N}, 4^{\circ} 03.11^{\prime} \mathrm{W}, 401 \mathrm{~m}$;

M 4 = off Vélez-Málaga, $36^{\circ} 38^{\prime} 10^{\prime \prime} \mathrm{N}, 4^{\circ} 03^{\prime} \mathrm{W}$, $300 \mathrm{~m}$ (grab sample).

The sediments was sieved through a $250 \mu \mathrm{m}$ mesh net. The retained fauna included the species of biogeographic interest reported here.

\section{PRIAPULIDA}

At present three species of Priapulida are known to inhabit the Mediterranean Sea; a fourth one is assumed to be present due to the recurrent presence of a distinct type of loricate larvae (for discus-

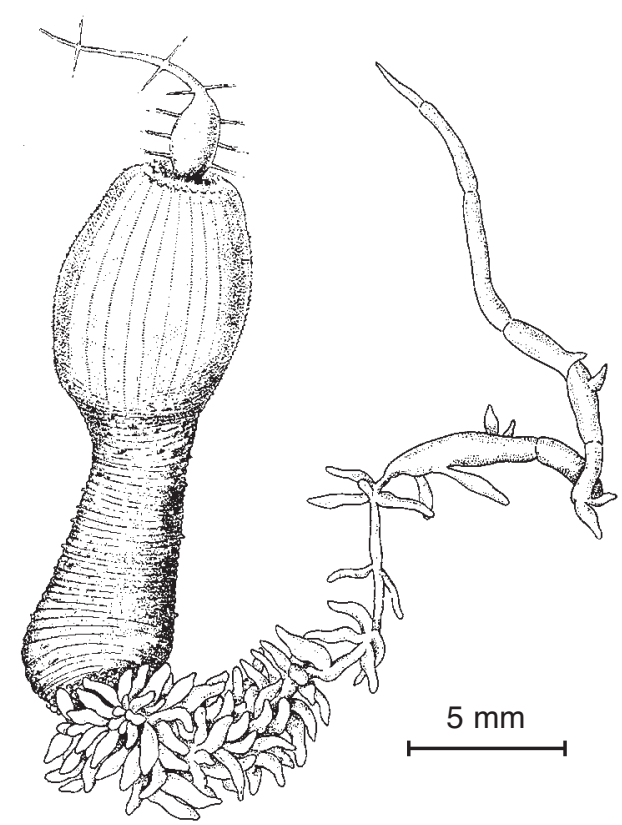

Fig. 1.- Priapulus caudatus from Greenland with a very elongated caudal appendage (and feeding on a polychaete); from Wesenberg-Lund (1937).

Fig. 1.- Priapulus caudatus de Groenlandia provisto de un largo apéndice caudal (y devorando un poliqueto); tomado de Wesenberg-Lund (1937).

\footnotetext{
* Institut für Zoologie der Universität Wien, Althanstr. 14. A-1090 Wien/Viena, Austria.
} 


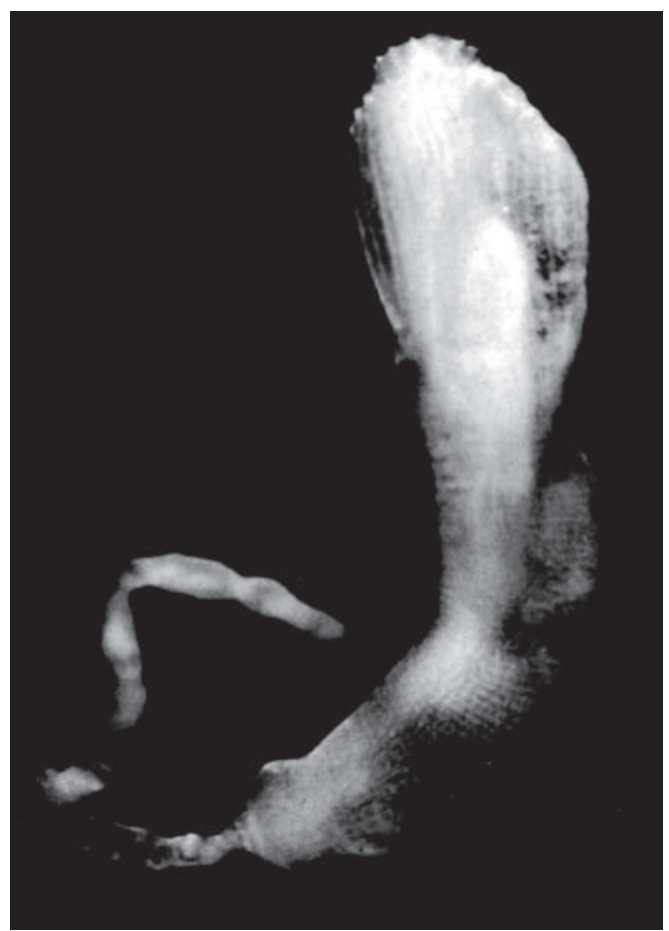

Fig. 2.- Photograph of the preserved Priapulus caudatus specimen from sample M 2; size $4.5 \mathrm{~mm}$ (without appendage).

Fig. 2.- Fotografía del ejemplar conservado de Priapulus caudatus de la muestra M 2; tamaño, sin apéndice, 4,5 mm.

sion see Salvini-Plawen, 1977). Up to now, Priapulus caudatus Lamarck, 1816 with a northern circum-polar distribution (Wesenberg-Lund, 1937), had only been collected from the Côte Vermeille off Banyuls (Guille \& Laubier, 1965; Land, 1970; Salvini-Plawen, 1977). This species possesses one caudal appendage which is often very long (fig. 1). The present new Mediterranean specimen is similar to this and was identified as a juvenile individual collected from sample M 2 (fig. 2). This finding thus is the first record of P. caudatus in the Iberian coasts (see Saiz Salinas, 1987).

\section{Caudofoveata (Mollusca)}

There is little knowledge on the occurrence of aplacophoran Mollusca in Iberian waters (cf. SalviniPlawen, 1997). Representatives of the molluscan class Caudofoveata, vermiform detritivores burrowing in sediment, have been found more recently off Barcelona: Scutopus ventrolineatus Salvini-Plawen, 1968, Prochaetoderma raduliferum (Kowalevsky,
1901), Falcidens gutturosus (Kowalevsky, 1901) and F. aequabilis Salvini-Plawen, 1972 (Salvini-Plawen, 1997). As had shortly been reported in the previous publication (Salvini-Plawen, 1997), the present samples also included records of Caudofoveata, viz. Scutopus ventrolineatus (one specimen each in M 3 and M 4), Falcidens gutturosus (1 ind. in M 1, 4 ind. in M 3), and Prochaetoderma raduliferum.

This latter species was identified in 6 individuals of sample M 1, as well as 1 specimen of M 2 and M 4. Their size ranged between $0.9 \mathrm{~mm}$ and $1.9 \mathrm{~mm}$, those beyond $1.2 \mathrm{~mm}$ has gonads, and all belonged to the fairly stoutish $P$. raduliferum f. brevis (fig. 3 ) as had been reported earlier (Salvini-Plawen, 1977). The sequence of scale types are arranged obliquely (as usual) towards dorsoposterior and the radula teeth (50-70 $\mu \mathrm{m}$ in size with $15-20$ denticles at the oral mid-edge; fig. 4) coincide with the characters discussed (1977). This contrasts to the specimens of "typical" $P$. raduliferum as described by Kowalevsky (1901) which normally show a continuously tapering posterior body (juveniles and larger specimens up to $5 \mathrm{~mm}$ in size), with at least one additional type (figs. $5 c, 5 d)$ of mantle scales. These scales vary in dominance and length according to body-size. The larger "typical" animals have larger-sized radulae (teeth 80$150 \mu \mathrm{m}$ in length with 18-35 denticles; see fig. 5) and the pharyngeal spatulae ("mandibles") measured vary correspondingly in size (200-250 $\mu \mathrm{m}$ x 80-110 $\mu \mathrm{m}$ in $P$. raduliferum f. brevis compared to "typical" specimens: $320-600 \mu \mathrm{m} \times 150-350 \mu \mathrm{m})$.

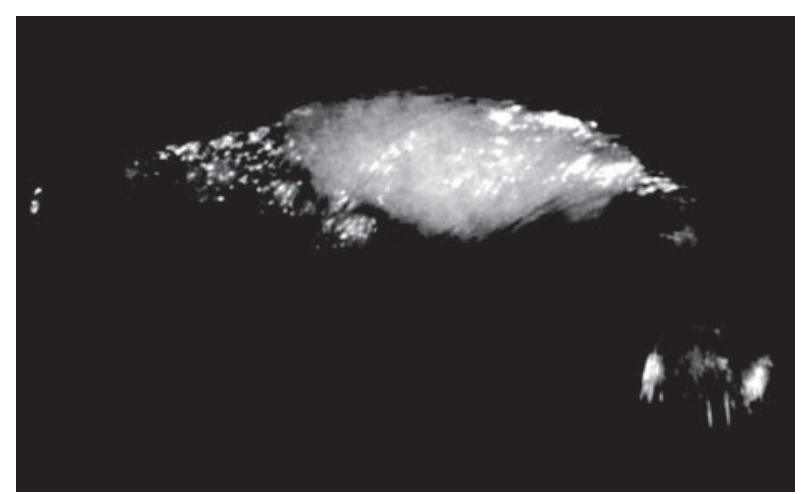

Fig. 3.- Photograph of a caudofoveate Prochaetoderma raduliferum f. brevis (with gonad) from sample M 1; total length $1.85 \mathrm{~mm}$

Fig. 3.- Fotografía del caudofoveado Prochaetoderma raduliferum $\mathrm{f}$. brevis (con gónada) de la muestra M 1; tamaño total $1.85 \mathrm{~mm}$. 

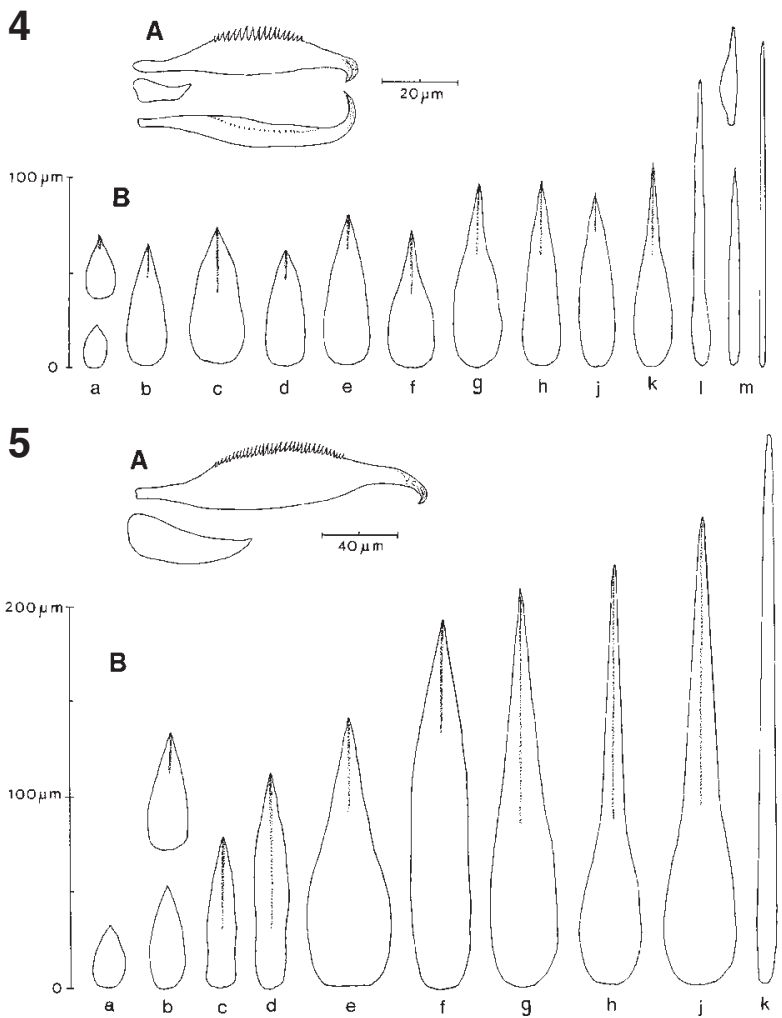

Figs. 4-5.- 4) Prochaetoderma raduliferum f. brevis from sample M 1 (1.6 mm in size): A) Two radular teeth (above accompanied by a squamous element of ribbon) from different views; B) sequence of mantle scales. 5) Prochaetoderma raduliferum, typical form from off Banyuls-sur-Mer $(3.5 \mathrm{~mm}$ in size): A) One radula tooth and a squamous element of ribbon (note different scale to fig. 3A); B) sequence of mantle scales.

Figs. 4-5.- 4) Prochaetoderma raduliferum f. brevis de la muestra M 1 (tamaño 1,6 mm): A) Dos dientes de la rádula (acompañados arriba de una escama cuticular de la membrana radular) en diferentes vistas; B) sucesión de las escamas del manto. 5) Prochaetoderma raduliferum, forma típica de Banyuls-sur-Mer (tamaño 3,5 mm): A) Diente de la rádula y escama de la membrana radular (nótese la escala, diferente de la fig. 3A); B) sucesión de las escamas del manto.

\section{SCAPHOPODA (MOLLUSCA)}

The only scaphopod species represented in the samples was Pulsellum lofotense (M. Sars, 1865). Six specimens between $0.9 \mathrm{~mm}$ and $2.8 \mathrm{~mm}$ were found in sample M 1, three specimens between 1.1 $\mathrm{mm}$ and $2.1 \mathrm{~mm}$ in length in sample M 3 . Pulsellum lofotense has not been found in this particular area, although Hidalgo (1917) reported it in

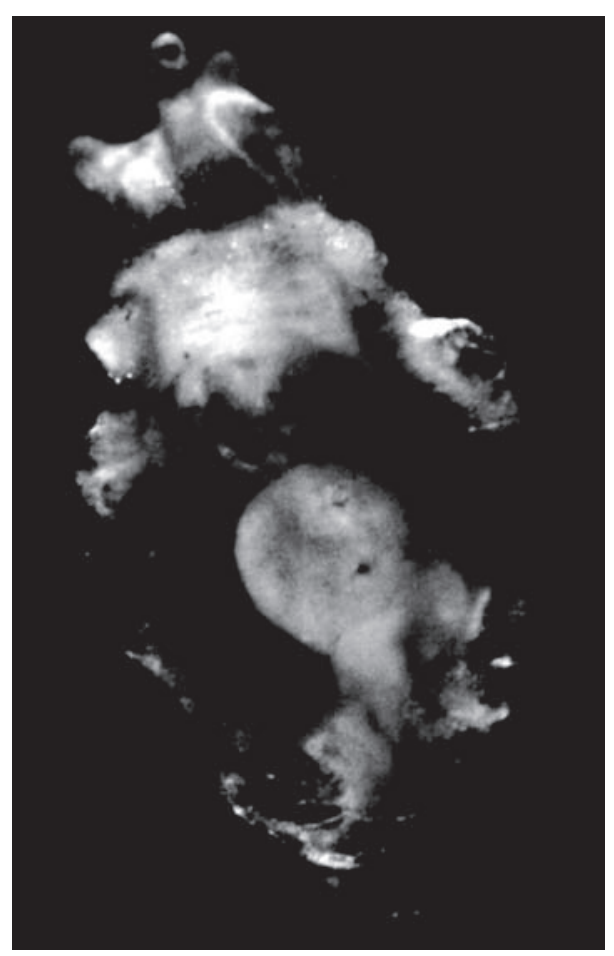

Fig. 6.- Photograph of preserved Myriotrochus geminiradiatus from $\mathrm{M} 1$, larger specimen.

Fig. 6.- Fotografía del ejemplar más grande conservado de Myriotrochus geminiradiatus de la muestra M 1.

north-eastern Spain, Steiner (1997) from the Gulf of Cádiz, and Locard (1898) from the Algerian coast. This finding strengthens the assumption of a continuous distribution of this species along the Iberian coasts.

\section{HOLOTHUROIDEA-APODIDA}

The sample M 1 taken off Málaga included two juvenile specimens of an apodan holothurian identified as Myriotrochus geminiradiatus SalviniPlawen, 1972 (fig. 6). This species is mainly characterized by a maximum of ten tentacles without digits and by few wheel-like skeletal elements, the spokes of which being differentiated as pairs (Salvini-Plawen, 1972). The two specimens measured $0.8 \mathrm{~mm}$ and $1.0 \mathrm{~mm}$ in size with five tentacles and five plus three smaller (growing) tentacles respectively. The skeletal elements are extremely few in number, viz. three wheels in the smaller individual and only one wheel fragment in the other. The 
wheels measure $30 \mu \mathrm{m}$ and $40 \mu \mathrm{m}$ in diameter, all possessing 16 double-spokes without bifurcation. The calcareous ring is built up of reticular plates.

Up to now $M$. geminiradiatus was only known from the northern and middle Adriatic Sea (SalviniPlawen 1972, 1977). This new finding enlarges its distribution into the western Mediterranean Sea.

\section{ACKNOWLEDGEMENTS}

We thank Dr. Juan A. Camiñas (Málaga) and his staff for the possibility to participate the ECOMALAGA campaing and thus enabling to collection of the samples. We are also grateful to Dr. Carmen Salas (Universidad de Málaga) for various help and support.

Work under the scope of the Fauna Iberica IV Project (PB95-0235)

\section{References}

Guille, A. \& Laubier, L., 1965. Découverte de la classe des Priapuliens en Méditerranée. Comptes Rendus de l'Académie des Sciences, Paris, 261(12): 11251128 .

HidAlgo, J.G., 1917. Fauna malacológica de España, Portugal y las Baleares. Moluscos testáceos marinos. Trabajos del Museo Nácional de Ciencias Naturales, Serie Zoología, 30: 1-752.

Kowalevsky, A., 1901. Sur le genre Chaetoderma. Archives de Zoologie Expérimentale et Générale, Sér. 3, 9: 261-283.

LAND, J. VAN DER, 1970. Systematics, zoogeography and ecology of the Priapulida. Zoologische Verhandelingen, Leiden, 112: 4-118.

LoCARD, A., 1898. Mollusques Testacés. Expeditions Scientifiques Travailleur et Talisman 1880-1883, 2: 1-1031.

SAiz Salinas, J.I., 1987. Especies de Priapúlidos, Foronídeos y Pogonóforos de la Península Ibérica e islas Baleares. Miscel.lània Zoològica, 11: 55-60.
SAlvini-Plawen, L.v., 1972. Zur Taxonomie und Ökologie mediterraner Holothuroidea-Apoda. Helgoländer Wissenschaftliche Meeresuntersuchungen, 23: 459466.

SAlvini-Plawen, L.v., 1977. Caudofoveata (Mollusca), Priapulida und Apode Holothurien (Labidoplax, Myriotrochus) bei Banyuls und im Mittelmeer allgemein. Vie et Milieu, 27(A/1): 55-81.

SAlvini-Plawen, L.v., 1997. Fragmented knowledge on West-European and Iberian Caudofoveata and Solenogastres. Iberus, 15: 35-50.

SteINER, G., 1997. Scaphopoda from the Spanish coasts. Iberus, 15: 95-111.

Wesenberg-Lund, E., 1937. The zoology of East Greenland: Gephyreans. Meddelenser om Grønland, 121(1): 1-25. 